there are also biologioal aspects of continually increasing importance to be considered. With regard to the functions of the directors of the new organizations, Lord Waverley explained that the arrangement does not imply functional management. Directors will not be responsible for particular establishments; but they will have a collective responsibility, and that is of the greatest importance in maintaining the balance between the different applications of nuclear energy. He thinks that there will be greater elasticity, greater freedom and less difficulty in maintaining the proper relations between those who are concerned in this work and scientists and technicians employed outside if it is organized in the way proposed under a non-departmental board than if it is under a public department of the conventional type.

Lord Waverley, and also Lord Salisbury in concluding the debate, referred to the question of salaries, and said they were both satisfied that this is likely to be handled more easily under the proposed arrangements than under Civil Service conditions. Lord Salisbury reiterated that what the Lord President of the Council will be concerned with is main questions of policy - financial and otherwiseand, in particular, the bolance of the use of this atomic material between the needs of defence, power, biology and so on, so as to ensure that the broad needs of Government policy in Great Britain are satisfied. With regard to budgeting, he added that only experience could show what system would be most appropriate. While it is not surprising that, for the present, the Government should wish to keep a firm control on the overall policy, grants in aid and quinquennial budgets may be required in future.

\section{NATIONAL WEED CONTROL CONFERENCE}

IN the United States, Canada and Great Britain 1 the post-war expansion in the use of herbicides is an almost unique example of the rapidity with which scientific discoveries have become integrated into agricultural practice. Between 1947 and 1952 the acreage of treated crops in the United Kingdom has risen from a few hundred thousand acres to more than two million. It is symptomatic of such a rapid rise that the science and technology concermed with chemicals for the selective or total destruction of plant life is yet without a name, while in Britain the interchange of results and technical information between research centres, the chemical industry, the manufacturers of equipment, spraying contractors and the farming community has so far been without adequate facilities. It was this need for a common meeting-ground that led to the setting up late in 1952 of a committee to organize a National Weed Control Conference, and on the committee were representatives of the Ministry of Agriculture, the Agricultural Research Council, the Association of British Insecticide Manufacturers, the British Agricultural Contractors Association and the National Farmers' Union. A three-day conference, under the presidency of Sir James Scott Watson, was ultimately held at Margate during November $3-5,1953$, and the attendance of 320 members is a measure of the spontaneous desire for the exchange of information.

The programme of the conference consisted of papers reviewing the place and value of herbicides in the several fields, together with $\varepsilon_{0}$ series of research reports and discussions at the end of each session. The economic losses due to weeds and the general role of herbicides in agricultural practice were reviewed by Sir James Scott Watson and by Dr. E. Holmes (Plant Protection, Ltd.), while the more specizlized problems arising in vegetable production, fruit culture and in forestry were considered respectively by the directors of the Vegetable Research Station and of the East Malling Research Station and the chief research officer of the Forestry Commission. The director of the Grassland Research Station and G. Maxwell Davies (National Agricultural Advisory Service) discussed the contributions that herbicides could make to grassland improvement, while the significance of weed seeds in relation to crop production was outlined by the director of the National Institute of Agricultural Botany. Various aspects in the design and performance of spraying machinery were surveyed by Dr. H. G. H. Kearns (Long Ashton Research Station), Dr. W. E. Ripper (Pest Control, Ltd.) and J. Cameron Gifford (Weed Control, Ltd.), while papers on the control of vegetation in ditches and on roadside verges were given by C. V. Dadd (National Agricultural Advisory Service) and E. C. Boyce (county surveyor, Gloucestershire).

The first research session was devoted to a consideration of the problems that have arisen in practice when the chlorinated phenoxyacetic acids, in particular, are applied to spring-sown cereals. The papers were concerned with three general aspects, namely, the direct effects of spraying on the crops, and on the weeds, and the overall effects which follow from treating a weed-infested crop. J. D. Fryer and J. G. Elliott (Oxford) gave an account of the field investigations which have been carried out during the past three years in conjunction with officers of the National Agricultural Advisory Service. For these cereal trials, weed-free crops were selected so that the variation in response due to the stage of development at the time of application could be directly assessed. Of the compounds tested, most attention was paid to the triethanolamine salt of 2 : 4-dichlerophenoxyacetic acid, which was applied at varying dosages $(0 \cdot 5-2 \mathrm{lb}$./acre $)$ either as a relatively concentrated spray ( 7 gallons of solution per acre) or in a more dilute form ( 80 gellons per acre). In all, during the three years some ninety-six field experiments, involving about three thousand plots, were laid down, and the trials were so sited as to cover most of the cereal-growing areas in England.

The results have brought out the great importance of timing correctly the application, since the proportion of malformed inflorescences and the type of malformity are highly correlated with the stage of development in the post-emergence phase. The results also demonstrated that the phase of maximal susceptibility occurs at a different stage of growth in oats as compared with wheat and barley. For a given dosage, oats, over all stages, are by far the most susceptible, and tentatively the conclusion has been reached that, in order to combine efficiency with the least risk of damage, the plants should be treated shortly after emergence above ground, that is, when they possess two leaves and have not yet started to tiller. In contrast, with both wheat and barley the stage of maximal susceptibility occurs when there are less than four leaves on the main stem, and the plants are most resistant when tillering has been completed. Within each cereal type there 
is cumulative evidence that varieties differ in their reactions to these compounds, and for oats this aspect was discussed by E. B. Seragg (North of Scotland College of Agriculture).

Miss Marjorie Myers (Boots Pure Drug Co.), on the basis of micro-dissections, brought out the points, first, that in cereals the time of spraying which ultimately results in a high proportion of deformities in the mature inflorescence coincides with the initiation and development of the flower primordia and, secondly, that in treated plants abnormalities in primordial development can be clearly distinguished. In fact, in the case of barley it is possible to detect the phase of development in a particular primordium at which the susceptibility is maximal. The development of the flower primordia is linked with the leaf number on the main stem, and in general once the sixth leaf has been formed the flower initials are complete and a period of relative resistance is reached.

At the present time there appears to be no immediate prospect of finding new compounds which will destroy some of the major weeds present in cereal crops, and, as Dr. A. Zeller (Pest Control, Ltd.) pointed out, emphasis should be laid on the selection of cereal varieties which have the ability to compete with weeds, while the importance of the nutrient status of the soil combined with skilled husbandry should not be forgotten as contributing factors. For example, the spread of wild oats in British cereal crops is causing alarm, and it would seem that the major remedial measures must consist of timing the cultivation and sowing of crops in relation to the life-cycle of both Avena fatua and ludoviciana. To do this demands, in the first place, intensive ecological studies of the two species, and the work described by Miss Joan M. Thurston (Rothamsted) illustrated how far management and rotational cropping could be brought to bear on this problem.

In the several investigations covering weed-free cereal crops, much evidence was obtained of the importance of formulation. In general, sodium salts cause the least damage and ester-oil emulsions in water the most, with the highly soluble amine salts in an intermediate position. Recent trials at Oxford (L. Kasasian) have, however, indicated that for some annual weeds the order of toxicity may be reversed. For example, in comparisons of the direct effects of chlorinated phenoxyacetic acids on Brassica arvensis, the sodium salts were the most phytotoxic. Similarly, K. Carpenter (May and Baker, Ltd.) stressed that, even when test plants are studied in a controlled and constant environment, varying the formulation of emulsions containing a single ester has differential effects on cereals and weed species.

The conference, besides discussing the control of perennial weeds in permanent grassland, also paid attention to the ancillary problem of the destruction of annual weeds in seed mixtures, sown either with or without a cover crop. It is a well-established fact that, compared to the grasses, leguminous species are more liable to injury by synthetic growth-regulators, especially in the seedling stage; and from studies of the direct effects of spray treatments either in the greenhouse (K. Holly, Oxford) or in the field (W. Ochiltree, of Plant Protection, Ltd., and E. B. Scragg), it can be concluded that red clover varieties are more resistant than the white and that for the red clovers $2: 4$-dichlorophenoxyacetic acid is more toxic than the corresponding methyl-chloro derivative. There was also some evidence that for white clovers the reverse is true. F. E. Alder (Grassland Research Station) considered that in some circumstances ammonium $2: 4$-dinitro-sec.-butylphenate has advantages for the control of some annual weeds during the phase of establishment, while both he and J.F. Ormrod (National Agricultural Advisory Service) concluded that for the control of dicotyledonous weeds in lucerne this nitrophenol is the most efficacious herbicide.

For the eradication of perennial weeds, discussion centred around some of the most important species, such as Equisetum palustre and Senecio jacobaea (ragwort), undesirable because of their toxicity to grazing animals, and rushes, because of their widespread incidence in marginal grassland. Investigations, conducted in south-west England by K. Holly, have shown that although the shoots of E. palustre are readily destroyed by spraying with either the dichloro- or methyl-chloro-phenoxyacetic acids at rates up to $3 \mathrm{lb}$./acre, regeneration soon takes place, and in consequence spraying alone cannot be regarded as a suocessful technique for their elimination.

Arising out of a comprehensive series of trials, conducted jointly by Oxford and the National Agricultural Advisory Service, it was clear that a very successful control of Juncus effusus can be achieved by doses of about $2 \mathrm{lb}$./acre of either of the two phenoxyacetic acids applied when the rushes are approaching the flowering stage. Cutting, either some time before or after the application, although beneficial, is not essential. In contrast, $J$. inflexus has proved much more resistant.

Although many trials have been carried out over the past five years to discover possible methods of destroying $S$. jacobaea, the results suggest that spraying alone with the synthetic growth-regulators cannot be regarded as a satisfactory solution. Under some conditions, a year after treatment there have been marked reductions in the total ragwort population, but in other trials, of apparently comparable nature, little reduction has been recorded. Studies of the changes in population on control and treated plots have brought out the need for further basic research on the ecology of ragwort. Whereas in some fields ragwort remained a relatively stable and persistent component of the sward, in others there was sometimes an inexplicable and almost magical disappearance of the plants during the winter months.

The important part that such ecological studies could play in deciding the best techniques for weed elimination were well illustrated by the investigations of Dr. J. L. Harper (Oxford) on the habitat requirements of the three commoner species of buttercups, Ranunculus acris, $R$. bulbosus and $R$. repens in grassland, and of A. Lazenby (Aberystwyth) on the factors governing the successful establishment of Juncus effusus. In the case of $R$. bulbosus, which in the mature state is relatively resistant to growthregulators, germination largely takes place in the autumn, whereas seedlings of the other two species appear in the spring. Thus, between species, the optinum time for spraying may well be different. It is worthy of note that the importance of this ecological approach was advocated not only by research workers but also by many speakers directly concerned with the manufacture of herbicides or their application in the field.

The great savings that could be made in nursery beds of forest seedlings by the use of mineral oils for weed eradication were clearly brought out by 
G. D. Holmes (Alice Holt), who, in conjunction with G. F. Barnsley (Shell), also discussed the potentialities of herbicides for the reduction of Calluna, prior to tree planting. Many investigations in the past have shown that the effectiveness of an arboricide is dependent on the rate and extent of its transport, and some preliminary results on the value of chromotrophic acid for detecting the movement of chlorophenoxyacetic acids in woody tissues were given by G. O. P. Eaton and G. F. Harding (Burt Boulton and Hayward).

Recently, trichloroacetic acid has shown promise for the control of some grasses, and A. L. Abel (Pest Control, Ltd.) gave an account of how this material could be used for elimination of Agropyron repens in Iucerne and other crops. The extraordinary persistence in the soil of one of the latest herbicides$p$-chloro-phenyl-N.N-dimethyl urea-was evident from the account given by Dr. E. K. Woodford (Oxford) of the work that has been undertaken at Oxford and the Vegetable Research Station. On the University Field Station, plots treated more than two years ago with $60 \mathrm{lb}$./acre are still almost free from vegetation, and $H$. A. Roberts added that at Wellesbourne, following on an application at the rate of $0.5 \mathrm{lb}$./acre in March, turnips sown in July were killed. Nevertheless, it would appear that this new material at very low dosages may be of value for the selective control of weeds in a few relatively resistant crops, such as carrots.

A number of papers related to the general problems of techniques of application.

The proceedings will be published early in 1954; a council was formed to arrange, inter alia, for future conferences.

\section{OBITUARIES}

\section{Prof. Matthew A. Parker}

THE death occurred on November 29 of Prof. Matthew A. Parker, at the age of eighty-two. Prof. Parker was for thirty-three years head of the Chemistry Department of the University of Manitoba, since the inception of that University as a teaching institution in 1904. On his retirement in 1937, he was honoured with the title of emeritus professor. Matthew Parker was a Scotsman, born in Renfrewshire and educated at the University of Glasgow, where he took the B.Sc. degree. After a year's postgraduate work at Heidelberg, he returned to his native Glasgow, as a lecturer at the Royal Technical College; he later became lecturer in organic chemistry in the University of Glasgow. While teaching in Glasgow, he collaborated with the late Prof. G. Henderson in the publication of a little book on qualitative analysis which was in use until quite recently at the University of Glasgow.

In 1904, Parker went to Winnipeg to establish the new Department of Chemistry which had just been created by the University of Manitoba. Prior to this date, the University had existed only as an exernining body. Along with Parker, three other professors were also appointed to direct three different science departments, namely, Swaile Vincent to physiology, Reginald Buller to botany, and Frank Allen to physics ; all of them have had distinguished careers.

On his arrival in Winnipeg, Parker found his department to consist of one laboratory, unfurnished, one lecture theatre, no staff but himself, and eight students. From this humble beginning he built up a Chemistry Department in the best traditions of Europe, and of Scotland in particular. Of necessity, the Department was for long a purely teaching institution; but Parker was always keenly alive to the necessity for research and, as his staff grew, he endeavoured to appoint men who would prosecute and encourage research. The First World War, and still more the depression, hampered development, but when he retired in 1937 (unhappily through an affection of the eyes-he had hoped to complete forty years of service to the University), the number of students in the Department had increased to eight hundred, and the staff to five.

Not only was Matthew Parker a great teacher, he was also a great personality. $\mathrm{He}$ was a splendid example of the genus Scottish gentleman-kindly, caustic, generous and shrewd. His interests extended far beyond those of science. His love of music amounted to a passion, and his knowledge of literature was wide. In these days of high specialization, there are few men who can lay claim to the wide culture of Matthew Parker. I am personally indebted to him for unbroken kindness and help, extending over twenty years. $\mathrm{He}$ is survived by his widow and his three daughters. A. N. Campbeli

\section{Dr. William Goodwin}

Dr. Wructam Goodwrn died at his home at Wye, Kent, on December 30, at the age of eighty.

He received his early training as a chemist in the University of Manchester, and his first post was that of an analyst to a commercial firm in Glasgow. It was here that he began his agricultural studies by attending evening classes at the Royal Technical College. In 1898 he left Glasgow and after a short time with an analyst in Manchester he went as research assistant to Prof. Senier at Queen's College, Galway. From there he was awarded an 1851 Exhibition Scholarship which enabled him to study in Germany under Prof. Tollens at Göttingen and at the Laboratory for Vegetable Physiology in Paris. Goodwin then returned, first to Manchester to carry out research in organic chemistry under Prof. W. H. Perkin, jun., and then to Göttingen, where he was awarded the Ph.D. degree. His long career in agricultural chemistry then began. After a few months as lecturer at Harper Adams College, he was appointed in 1907 to succeed Sir John Russell as head of the Chemistry Department at Wye College, Kent. Four years later he became principal of the Midland Agricultural College, Nottingham, a post which he held for eleven years; in 1922 he returned to Wye College as advisory chemist, where he remained until his retirement in 1938 .

In addition to his advisory work, Goodwin made substantial contributions to research in many branches of agricultural chemistry, but particularly in the field of crop protection. He was also well known as an examiner and for his translations into English from the German of Kellner's "The Scientific Feeding of Farm Animals" and Barthel's "Methods used in the Examination of Milk and Dairy Products". At the time of his derth, Dr. Goodwin was one of the oldest members of the Chemical Society.

He leaves a widow and two daughters.

R. L. WAIN 